本セクションでは今年の 3 月号で「ES 細胞」について取り上げましたが、再 生医療の実現に向けては、もう 1 つの万能細胞「iPS 細胞」をめぐって、国 際的に研究競争が激化しています。

今回は、ヒト細胞では初めて、ウイルスを使わずに iPS 細胞を作製した研 究成果についての記事を読んでみましょう。

\title{
NEWS
}

語数： 339 words 分野: 細胞・遺伝・発生

Published online 1 March 2009 | Nature 458, 19 (2009) | doi:10.1038/458019a

http://www.nature.com/news/2009/090227/full/458019a.html

\section{Virus-free pluripotency for human cells}

Stem-cell advance could bring tailored treatments closer.

\section{Erika Check Hayden \& Monya Baker}

1. For the first time, specialized human cells have been transformed into a state similar to that seen in embryonic stem cells, without using viruses. The advance edges stem-cell biologists closer to clearing a barrier to using reprogrammed cells for therapies and drug screening.

2. "The field has been waiting for these papers," says Marie Csete, chief scientific officer at the California Institute for Regenerative Medicine in San Francisco.

3. Embryonic stem cells are pluripotent - capable of generating all the body's specialized cell types - and creating tailor-made cell lines might allow scientists to better study human diseases and test possible treatments. That looked difficult until 2006, when Shinya Yamanaka and his colleagues at Kyoto University in Japan reported that they had reprogrammed mouse skin cells into an embryonic-like state by infecting them with a virus containing four genetic factors. Yamanaka called the reprogrammed cells induced pluripotent stem (iPS) cells.

4. Since then, scientists have used various viral vectors to reprogram human cells with the 'Yamanaka factors', and have used non-viral methods to reprogram mouse cells. No one had been able to reprogram human cells without

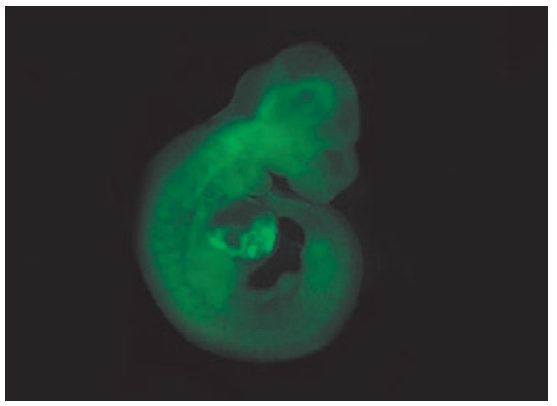

ウイルスベクターを用いないで作製されたマウス iPS 細胞を導入してできたキメラマウス胎児。 using viruses - which integrate unpredictably into the genome - until now.

5. Stem-cell researchers led by Andreas Nagy, of the Samuel Lunenfeld Research Institute at Mount Sinai Hospital in Toronto, Canada, and Keisuke Kaji, of the University of Edinburgh, UK, inserted genes encoding Yamanaka's factors into a piece of DNA, or cassette, that also contained a jumping gene known as piggyBAC. The teams showed that this cassette could be inserted into the DNA of mouse and human skin cells and could reprogram them back to an embryonic-like state (K. Kaji et al. Nature doi:10.1038/ nature07864; 2009, K. Woltjen et al. Nature doi:10.1038/ nature07863; 2009).

6. The teams then used an enzyme called transposase to remove the cassette from the mouse cells. But some scientists say that until the cassette is removed from human cells, the technique is not a major advance over viral methods.

7. Nagy, however, is confident that he will be able to use transposase to remove the cassette from human cells. He is currently trying to use his method to reprogram cat and dog cells. 


\section{TOPICS}

iPS 細胞とは?

iPS 細胞 (induced pluripotent stem cells；人工多能性幹細胞）は、 京都大学の山中伸弥教授らによって初めて作製された、人工的に多能性を 誘導した細胞である。動物は、1つの細胞（受精卵）が組織や器官に分化 して、個体となる。このように細胞はもともとさまざま組織になれる、多能 性をもつ。ところが、動物では通常、発生のある時期を過ぎて分化が進ん でしまうと、元の多能性をもつ細胞へは戻れない。多能性をもつ細胞にす るには、細胞を胚の状態に初期化（再プログラム化）する必要がある。山 中教授らは、初期化因子として4つの遺伝子 (Oct3/4、Sox2、c-Myc、 KIf4；これらは山中ファクターとよばれる）をレトロウイルスベクターに組 み込み、マウスやヒトの培養皮膚細胞に導入し、初期化に成功した。初期 化されたヒト皮膚細胞からは、心筋細胞、神経組織、腸管様組織、軟骨組 織などが形成された。このようにiPS 細胞は、通常の組織から採取した細 胞から作製できるので、受精卵を使用する $E S$ 細胞と違って倫理上の問題を 考慮せずに、再生医療に利用できる。ただし、導入遺伝子やレトロウイル スベクターに発がん性があり、iPS 細胞のがん化の可能性を否定できない。 そこで、さまざまな改良が進み、発がん性を示す $c-M y c$ を使用しなくても iPS 細胞を作製できるようにしたり、iPS 細胞作製後、導入遺伝子を取り除 く方法が考案されたり、遺伝子を使わずに直接タンパク質を細胞に入れた りする方法が考案されている。この記事では、レトロウイルスベクターを使 用せずに初期化遺伝子を導入する方法について概説している。

\section{SCIENCE KEY WORDS}

リード tailored treatment(s): オーダーメード医療

患者ひとりひとりに合わせた治療。例として、患者の DNA 情報から、 それぞれに合わせた治療を行うことが挙げられる。iPS 細胞の場合、 患者から採取した細胞から作製できるので、拒絶反応のない再生組織 を移植できる。

1. reprogrammed cell(s): 初期化（再プログラム化）された細胞

上記 TOPICS の解説のように、細胞は一度分化してしまうと、元の多 能性をもつ細胞には戻れない。この性質をリセットして、細胞に多能性 を復活させることを再プログラミング、または初期化という。

3. genetic factor(s): 遺伝因子

遺伝子とほぼ同義語。場合によっては、遺伝子産物（タンパク質）を 示すこともある。

4. viral vector(s): ウイルスベクター

ベクターとは、目的の外来性遺伝子を、目的の細胞（細菌や酵母、動 物細胞など）に導入し、宿主細胞内で維持・増殖し、発現できるよう にするための媒体核酸。目的や導入する宿主細胞に応じて、さまざま な種類のものがある。このうちウイルスベクターは、ウイルス遺伝子 の毒性部分を取り除いて構築したベクターで、通常、人工的に構築し たベクターよりヒト細胞への導入効率が高いが、安全性に問題が残る。

\section{WORDS AND PHRASES}

1. specialized human cell(s):「分化したヒト細胞」

specializedは、ここでは differentiated（分化した）という意味 で用いられている。幹細胞の分裂によって生じ、機能や形態が特殊化 した分化した細胞（例えば筋細胞や神経細胞。この記事では皮膚細胞） で、多能性はないか、ほとんどない。

1. (be) transformed into 〜 :「〜に形質転換する」

1. edge(s) A closer to 〜 :「Aを〜に少し近づける」

「じりじり近づける」というニュアンス。

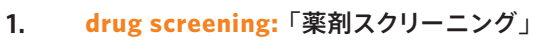

臨床試験に先立ち、動物実験や in vitro 実験によって、薬剤候補の生 物学的作用や毒性作用を調べること。

3. generate[-ing]: 「生成する」

3. tailor-made cell line(s):「特定の条件に合わせた細胞系」

4. integrate unpredictably into 〜 :「どのようにゲノムに組み込まれる のかが予測できない」

integrate into 〜は、「〜に組み込まれる」の意味。unpredictably は、その状態が予測不能なこと。

5. inserted genes encoding Yamanaka's factors into a piece of DNA, or cassette:「DNA 断片（カセット）に山中ファクターをコード する遺伝子を挿入した」

gene(s) encoding 〜 は 「をコードする遺伝子」。insert(ed) A into B は、「AをBに挿入する」という意味。

特に、宿主細胞のゲノムに組み込まれるレトロウイルスベクターは、宿 主遗伝子の活性を変化させる可能性があり、白血病の発症なども報告 宿主遺伝子に組み込まれないのでレトロウイルスベクターより安全性が 高いが、導入遺伝子の発現が一過性であり、持続的な発現を必要とす るiPS 細胞の作製では使用がむずかしい。

ゲノム上のある場所から、別の部位へ移る（転移する）DNA 単位。卜 趴部位に入り込んで、挿入先の 誘発しゲノム再編成にかかわったりする。近年、この性質を利用した、 ウイルスベクターより安全性の高いトランスポゾンベクターの開発が進 んでいる。

トランスポゾンが転移するとき働く酵素。トランスポゼースは、通常、 的 端にある逆方向反復配列（IR）を認識して切り出し、転移部位での再 結合を行う。 
参考訳

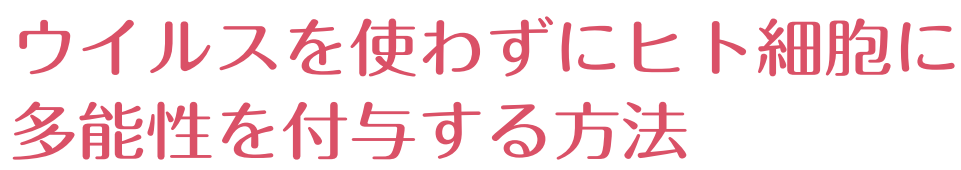

この幹細胞研究の進展で、オーダーメード治療が実現に近づくかもしれない。

エリカ・チェック・ヘイデン＆モー二ャ・ベイカー

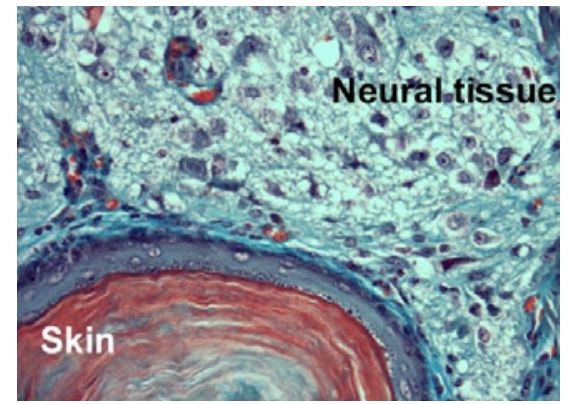

今回ウイルスベクターを用いないで作製された マウスiPS 細胞からできた神経組織。
1. 分化したヒト細胞を、ウイルスを使うことなく胚性幹細胞（ES 細胞）に似た状態へと形質転換する試みが、このほど初めて成 功した。これにより幹細胞生物学者は、初期化した細胞を治療 や薬剂スクリーニングに利用することへの障害の 1 つを、解決 に向けて少しだけ前進することができた。

2.「幹細胞生物学者は、こうした論文を待っていたのです」と、カ リフォルニア再生医学研究所（米国、サンフランシスコ）の最 高科学責任者 Marie Csete は話す。

3. ES 細胞は、体内のあらゆるタイプの特殊化した細胞を生成す る能力 (多能性) をもっている。この性質を利用して用途に合 わせた細胞系を作製できれば、ヒ卜疾患をさらに詳しく研究し、 治療法となりうる方法を検証できる可能性が生まれる。そのよ うな研究は困難だろうとみられていたが、2006 年に京都大学 の山中伸弥教授らがマウスの皮膚細胞を初期化して ES 細胞に 似た状態にすることに成功したと報告すると、状況は一変した。 ここで山中教授らが用いたのは、4つの遺伝因子をもつウイル スをマウスの皮膚細胞に感染させるという方法であり、初期化 されたこの細胞は人工多能性幹細胞（誘導多能性幹細胞；iPS 細胞）と命名された。

4. 以来、科学者はさまざまなウイルスベクターを使って「山中ファ クター」をヒト細胞に導入し、これを初期化してきたが、マウ ス細胞の初期化には、ウイルスを使わない方法が用いられてき
た。ウイルスを使う方法には、どのようにゲノムに組み込まれる のか予測できないという欠点があるのだが、ウイルスを使わず にヒト細胞を初期化することはどうしてもできなかった。

5. 今回、マウントサイナイ病院サミュエル・ルーネンフェルド研究 所 (カナダ、トロント) の Andreas Nagy とエディンバラ大 学（英国）の梶圭介をそれぞれリーダーとする2つの幹細胞 研究チームは、ジャンプする遺伝子（トランスポゾン）の一種 である piggyBAC を含む DNA 断片（カセット）に、山中ファ クターをコードする遺伝子を挿入した。そして、このカセットを マウスとヒトの皮膚細胞に導入し、これらをES 細胞のような状 態に初期化できることを明らかにした（K. Kaji et al. Nature doi:10.1038/nature07864;2009, K. Woltjen et al. Nature doi:10.1038/nature07863; 2009)。

6. 両チームは、トランスポゼース（トランスポザーゼ）という酵素 を使って、このカセットをマウス細胞から除去することにも成功 した。しかし、一部の科学者は、ヒト細胞からカセットを除去で きるようになるまでは、ウイルスを使う方法から大きく前進した ことにはならないと指摘している。

7.これに対してNagy は、トランスポゼースを使ってヒト細胞から カセットを除去できるようになることを確信している。彼は現在、 ネコとイヌの細胞の初期化について、この方法を試している。 